\title{
A Case Study Based on the Wondrous Order Plants Table
}

\author{
Michal Yakir, Israel
}

\section{Case of a Child Suffering from Ear Infections}

This is a case study of a four-year-old child, arriving with his mother for a first consultation on 28.4.10.

Observation: a delicate looking child, with an adorable smile. Plays with the fairies and butterflies on my desk.

The problem for which they approached me: repetitive ear infections.

The child suffers from a common cold most of the time. The mother tells me that since he was a baby he suffered from recurring ear infections, a condition accompanied with secretion from the ears.

He constantly suffers from the common cold, which became a chronic condition with a constantly stuffed nose.

The last ear infection occurred a month ago, when he was found to have enlarged adenoids, a third tonsil and an air blockage.

The teacher in his playschool thought his hearing was decreasing. Medical findings showed a slight decrease.

He grinds his teeth at night, especially when it is noisy - for instance, when his baby brother cries.

Still wets his bed at night.

The mother narrates

"He has two older brothers $(8,11)$ and a younger one-year-old brother (received him relatively well, pretty much ignores him...)

He is an amazing child, he becomes acclimatized quickly everywhere. He is very cool and gets along with everything. He has no anxieties during day-to-day life. He was always a calm child, and this is why I decided to have yet another baby... but perhaps, something which is suppressed during the day surfaces at night? During the day he is calm, but a medium we consulted suggested his anxieties are related with a past life. ... He is occupied with what happens when one dies, what will happen when he dies? When his mother dies?

He is a sensitive child, and highly sociable. $\mathrm{He}$ is friends with everyone in his playschool; when he sees someone from afar he will call him even if he is on the other side of the street. He is also quick to befriend new children.

He has a highly developed imagination and a high ability to concentrate; he can occupy himself on his own.

He likes cuddling, falls asleep at night while stroking me. He is good with girls. He is not a fighting, physical boy. (Strokes himself with a feather at my office.) Knows how to express love, to cuddle and hold, can even hug and kiss his friends from time to time.

Communicates, like my husband, something optimistic, happy and safe. However, like him, he is addicted to control: he is bossy, tries to dictate the course of events so that things will go the way he intends them to. He dislikes changes. Rigid, even though from the outside he appears soft and sweet.
Highly competitive - he has to be in first place, it is very important to him, to be number one - with his siblings in particular, even though he is younger than they are. When his siblings fight he tells them he is friends with both of them. On the one hand he competes with them and on the other, it is highly important that everyone likes him. Should one brother tell him, "I am not your friend" - he wants to die. This really threatens him. It is highly important that they will not be angry with him. If I am angry with him - he is worried about it, from a young age".

He is short for his age.

Cravings: Sweets (3) especially lollipops, purple, pink and red ones. He likes to eat chocolate and cheese. Otherwise he is not much of an eater.

He is not fond of tomatoes (recently) and potatoes.

Pregnancy was desired and healthy but the labor was induced (Pitocin) since he was not yet born by his due date. "The hospital pressured us to induce the labor, but it was unnecessary. The birth was horrific, and I went through immense pain. I felt horrible contractions - the worst pain I ever felt."

Speech late: it took a while until he spoke. To this day he mispronounces words.

Pimples? The mom suffered from them as a teenager, the father did too.

\section{Case Analysis}

In approaching this case I used the Table of Plants structure (see further details later on), as the case demonstrates clear indications of the fifth column in the Table: the competitiveness, bossiness, his need to control others, to be the first, to be "taller". All that points to the fifth column. His need to establish relationships, his needs to please others, to be likeable in a charming way along with excessive emotional sensitivity, occupation with the world beyond,

\section{S U M M A R Y}

This case demonstrates the use of my system's table of plants in arriving at and deciding the remedy - and understanding the reasoning in this case.

KEY WORDS Table of Plants, Rosales, Rosa damascena, Wondrous Order 


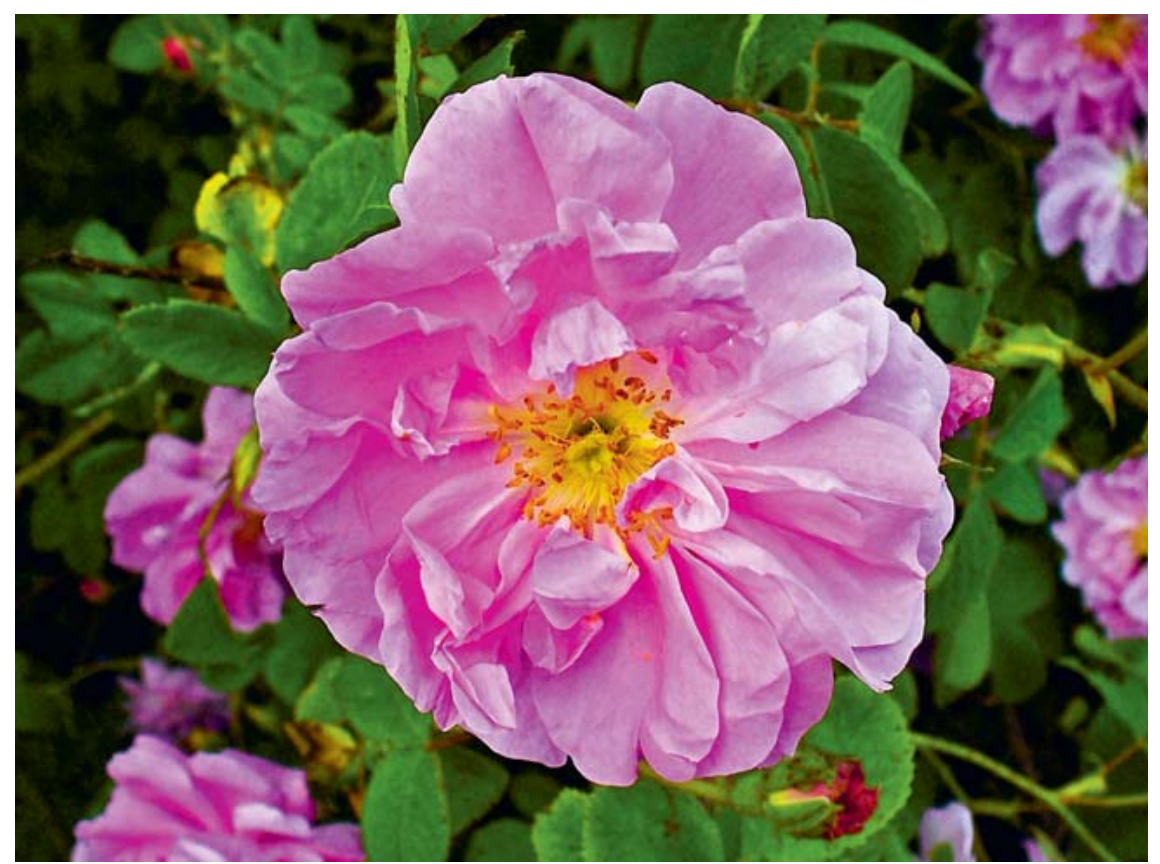

Fig. 1 Rosa damascena (Damask rose).

Table 1 Repertorization using RADAR program.

\begin{tabular}{|c|c|c|c|c|c|c|c|c|}
\hline & \multicolumn{2}{|l|}{ Repertorization } & \multirow{2}{*}{$\begin{array}{l}\text { ros-d. } \\
3 / 3\end{array}$} & \multirow{2}{*}{$\begin{array}{l}\text { nux-v. } \\
2 / 3\end{array}$} & \multirow{2}{*}{$\begin{array}{l}\text { sil. } \\
\text { 2/3 }\end{array}$} & \multirow{2}{*}{$\begin{array}{l}\text { staph. } \\
2 / 2\end{array}$} & \multirow{2}{*}{$\begin{array}{l}\text { lac-leo. } \\
2 / 2\end{array}$} & \multirow{2}{*}{$\begin{array}{l}\text { aur. } \\
1 / 3\end{array}$} \\
\hline & & & & & & & & \\
\hline 1 & $\begin{array}{l}\text { MIND - ANGER - contradiction; } \\
\text { from }\end{array}$ & 75 & 1 & 2 & 2 & 1 & 1 & 3 \\
\hline 2 & $\begin{array}{l}\text { MIND - COMPETITIVE - brother or } \\
\text { sister with* } \\
\text { (A symptom I added to the reper- } \\
\text { tory, based on my clinical experi- } \\
\text { ence and Chetna Shukla's proving) }\end{array}$ & 2 & 1 & - & - & - & 1 & - \\
\hline 3 & $\begin{array}{l}\text { EAR - EUSTACHIAN TUBE; com- } \\
\text { plaints of }\end{array}$ & 15 & 1 & 1 & 1 & 1 & - & - \\
\hline
\end{tabular}

thoughts about death and ghosts - all point to the first row, particularly with the history of an early-induced labor, which is a clear indication of a "pre" process, or the first row.

There is an excessive need to please, the gentleness, the desire to hug, kiss and cuddle, and the desire for sweets; the "pink" aura that surrounds the entire case. All these point to the Rose family (which is situated in the beginning of the fifth column).

Out of the Rosales, Rosa damascena has a known affinity to ear pathology, and issues with height and competitiveness. Thus it was chosen as the remedy for the case (see Fig. 1 and Table 1).
Prescription: Rosa damascena C12 once daily

\section{Follow-up}

\section{After two months}

A day after taking the remedy for the first time he developed a high fever which, within one day, was gone, on its own. Since then he has been healthy, apart from one occasion on which the parents went abroad and he was in playschool. He got sick but recovered two days after his parents returned. He was healthy until a flu epidemic erupted at school a few days ago. His parents travelled and left him with his grandparents: he woke up saying that his body hurts and he cannot go to playschool. Has a cough, which is rather deep, but no sinusitis even though he suffers from a slight common cold.
He does not eat well. He only eats candies and cakes.

The teeth grinding decreased, but it still exists.

He does not wet his bed that much.

The competitiveness is still there: he must be first to receive the food; he fights over his place with his elder brother, even though he loves him. Apparently, the issue is his young brother; it seems now that he would have been happy to give him away. The jealousy is out.

He is more insolent and rebellious than before. He used to be a conformist child. He used to do anything to make you like him. Now he threatens to leave the house when things are not done his way.

Prescription: Switch to fluid Rosa damascena C12, 1 drop daily

Again two months later

Bed-wetting ceased entirely: one day he simply asked to sleep without a nappy and has been dry since.

Teeth grinding has almost stopped. His sleep is calmer.

He no longer suffers from the cold.

Mentally - he is calmer, less agitated, has less tantrums, is still competitive with his brother and sister but the most clear change is individualism, which was absent beforehand. This can be seen with his friends: if they do not want to play his games - he goes on to play by himself, and does not try to please them. He began taking his remedy by himself (with a shy and engaging smile he tells me that his mother helps him. So this quality of the remedy is still there).

Prescription: Raise potency to Rosa damascena C 15 - 1 drop a day.

Later on, we further increased the potency to $\mathrm{C} 18$.

\section{Again two months later}

Physically he is fine. Hearing is normal. Sinuses clean. No cold. The jealousy for his brother also passed and he is very nice to him. Also, the anxiety level decreased significantly. In playschool he is highly popular, a leader. Wants things to be done his way - rather spoiled... 
In the following winter they came for an additional session as he had a slight cold and some teeth grinding. He has fears of ghosts. Again his mother tells me he is very popular among his friends; he is bossy but in a sweet manner (he intervenes and says: "I am going to dress up as a king."). He likes to feel soft fabrics, strokes his mother's sleeve before falling asleep. Again, he is jealous of the attention that the older sibling provides his sister.

Now we refer to his eating habits: he is still a very picky eater and will not touch many types of food. Eats a small variety of fruits and vegetables and still prefers sweets.

Prescription: Increase to Rosa damascena C30 1 drop daily

\section{Fifteen months after intake}

Still takes Rosa damascena C 30.

The cold is gone and for the rest of the winter he did not suffer from it.

Sleeps well.

His eating habits have improved. All of a sudden he has an appetite.

It turns out that there was something they never reported: a tendency for weakness with heart involvement: it appears he would get tired easily. Also, when he competed with a friend, if the friend was about to beat him, he would complain that his heart aches. This has improved as well.

He remains bossy.

Treatment: continue for another month with Rosa damascena C30 and then increase to C200. Single dose.

\section{Two months later}

The parents report that all is well. Should the need arise, they will give a single dose of Rosa damascena C200.

\section{The Structure and Methodology of the Plant Table}

Plants are the source of nature's ability to evolve and develop. Observing nature, we learn that development is inherent to the essence of the plants kingdom. Continuously growing ${ }^{1}$ and ever evolving, plants adapt to nature and create it at the same time.
Plants were the first to fashion the idea of separation in nature: Unlike minerals, plants have a membrane separating them from the environment, an attitude that allows them to develop along their own evolutionary lines and pace, which is a quicker one than the minerals'. The evolutionary changes plants go through propel evolutionary changes for the whole biosphere, including the atmosphere, minerals and animals.

More so, plants are the foundation for the existence of life, providing oxygen, carbon and nutrition. Plants propel minerals from earth outward and from the air inward into the earth, availing it to the biosphere, allowing growth and continuation of life on earth. In this sense, the plants kingdom acts as a stirring mediator between the worlds, expressing an archetype of continuous growth and development.

In accordance with its developing nature, the plant kingdom's evolution can be seen to correspond with human psyche development, seeing that both share the innate nature of growth and development. At times where development is halted, manifesting as a disease, the corresponding plant can be summoned. This is one more gift the plant world offers.

The Plants schema structure expresses this correspondence in a manner akin to the homeopathic understanding of the Periodic table of elements; its axes, however, are founded on evolutionary stages of botanical development. The building block of the table is not a single plant or a remedy, but a whole botanical group. Thus every square of the table contains one or few Orders ${ }^{2}$ or Families. The reason the Plants schema doesn't present specific remedies as its building blocks is that while the Mineral Kingdom contains 118 elements, the Plant Kingdom consists of thousands of plants which necessitated aggregating them by groups - namely Families and Orders.

I found Cronquist's ${ }^{3}$ systematics suitable for the table's scheme as it is led by evolutionary vision, being grounded mostly on homeopathic-like "signs and symptoms" of function and sense in the Plant Kingdom.

When the table is systematized in such an order, with vectors of botanic evolution, it

\footnotetext{
1 Most of the plants continue to grow and gain mass all their life.

2 Order is a higher taxonomic rank above Family.
}

becomes quite easy to decipher the homeopathic sense of it by assembling the Materia Medica information from all the remedies within each family - "as if one remedy", and interpreting it according to its location in the table. In an astonishing order, the axes of botanical development and their correspondent remedies are found to parallel stages of human development.

This way, each square in the table presents a convergence point of two axes - Ego construction and levels of growth and development: the horizontal axis is formed by separation and individuation stages while the vertical axis forms maturation levels. This provides physiological, emotional and mental content to each family of plants. While Families of plants present the collective themes that correspond to any given location on the table, a single remedy describes only certain variations of those themes.

The Table of Plants thus provides a schema that links plants' developmental stages to human developmental stages. The table refers to the challenges and obstacles met during the developmental journey of the Ego from a primary stage of union and oneness to an advanced stage of individuality. Learning and absorbing the lessons of the feminine and the masculine elements.

The Plants table provides reason and explanations to remedies, as well as to qualities of families of remedies. It allows better understanding of cases, as well as promoting understanding of small remedies and new provings. The Plants table can provide an understanding as to why the remedy displays certain characteristics as well as to why a case calls for a remedy belonging to a certain Family. The beauty of the plant table's systematics is that, without contra-

\footnotetext{
3 In the 1980s, the botanist Arthur Cronquist (1919-1992) postulated a systemic scheme of classification that defined the evolutionary processes of plants in a way that created a clear association between families, orders and higher taxonomic rank. Cronquist's system places flowering plants into two broad classes, Monocotyledons and Dicotyledons, divided into subclass categories, where related Orders, Families and Species are placed by certain morphologic order. Arranged from primitive to advanced, the inner order is decided by appearances, signs, and symptoms (as in homeopathy), by the evolutionary advancement of the flower, fruit, pollen and seed structures. In this narrative, the most primitive plants are positioned in the base of the tree; the most advanced plants appear in the topmost part of the tree.
} 


\section{Table of Plants Attributes}

\section{Columns}

The columns present the 10 botanical Subclasses of the table, portraying a transformative journey of differentiation, separation, independence and individuation, while aspiring toward freedom from the Ego boundaries. The "Ego" is transported from a state of oneness, from the whole, indistinctive "Self", towards formation and realization as an individual Ego - preparing to shed its Ego layer again, wiser than before. From unity to individuation and back to unity again. The journey is initiated by contending with the feminine element. Once the lessons are learned, separation and a split from the feminine element occur, the struggle shifts, and the Ego has to face the masculine element. Gaining the masculine element's experience and lessons allows departure from the Ego closure and progression toward interaction and a relationship with "the other" and with the world at large. From union and oneness to a differentiated Ego, now able to be part of the outer world, to cooperate and unite again, yet retain its distinctiveness and unique presence.

In the developmental journey as presented by the columns, the human soul as- pires to acquire awareness, consciousness, identity and uniqueness, subsequently returning to the source, this time though as a conscious part of the whole, a witness of creation's wondrous harmony.

The Columns' attributes are loosely linked to C.G. Jung's stages of development of the Ego. More about that in Wondrous Order, the systematic table of plant remedies.

\section{Rows}

The Rows present large botanical groups describing levels of development and maturation within each column, beginning with pre-birth and proceeding with infancy, childhood, adolescence maturity and finally old age.

Rows' attributes are based on Erik Erikson's human development stages [2].

\section{Intersections}

Meeting points of rows and columns: Each column presenting as a stage of Ego separation and individuation progresses accordingly, expressed within itself through nine levels of readiness and maturity, presented by the rows. diction, it complements and adds depth to case analysis, regardless of whether the approach is of a conservative or modern homeopathic method.

\section{Extended description of the essence of the columns}

The First Column (Unity) depicts an initial state of awareness to the unified feminine quality element that, by its nature, gives birth and initiates processes. The first column represents a unity with the infinity from which everything bursts, and is symbolized by water, first chakra and more. Problems or lessons related to the first column can be expressed as a lack of boundaries and discrimination, a weak, dependent and influenced Ego, spaced out and inattentive. A state of awareness might be there, yet the inability to act. Typical remedies are: Op, Staph, Arist, Lotus, Asar, Nux$m$, Acon, Puls.

In the Second Column (Here or There) the initial separation begins (a first masculine impulse enters the process of the table), followed by a sense of smallness and weakness, as effort is put into "standing by oneself". Issues presented are related to being small or big, being in this world or remaining in the other world (or remaining in any other previous state). Here or there, indecision, "should I return to the unified state or should I separate?" "Will I create boundaries or will I have them blurred?" Remedies such as Cann-i, Urt, Ficus and Quercus are characteristic to this column. The struggle and lessons are still in the territory of the feminine quality.

In the Third Column (The Hero), there is a strong and intensive battle to separate from the feminine-maternal quality that though before gave life, is now perceived as strangling and limiting. Expressed as a struggle to separate from anything that appears "controlling", the developing Ego fights for its individuality: with the characteristic statement: "I want to do it my way". Characteristic remedies are the various Cacti.
In the Fourth Column (Nurturing and Maturity), the maternal element is attaining maturation. After the previous column's journey in the feminine element, the individuation process reaches a stage where it necessitates gaining equanimity: an ability to nourish or be nourished, provide, give or take without being belittled for it. The lesson obtained is maturity of the maternal quality, an ability to give or receive yet keep your separate individual identity. Imbalance at this final maternal column would be expressed as mother/daughter issues, family issues, complications related to motherhood and elements of abandonment and dependency. We shall often see overresponsibility for the family, anxiety about family matters and carrying the burden of family, which sets the ground for exhaustion of personal energy, fatigue and back pains. Eating and digestive disorders will often ensue. Typical remedies are Bamb, Sacc-a, Trit, Cypr, Thea, Choc, Bry, Brass, Sin-a.

In the Fifth Column (The Other), the Ego is already solid and constructed. In order to continue its development, the Ego must attend fully the lessons of the masculine quality, which creates boundaries, rules and separation, giving purpose and direction. By the masculine borders, the Ego is enabled to realize what is apart from himself, to separate from what is not himself and thus come to meet the other, as an individual by itself. This separation allows a mature relationship to be created, so that is why the subject of relationship is of utmost importance, especially in its beginning (i.e., the Rose family). Later on the emphasis turns to the expression and fulfilment of one's role outside the family, to doing and acting. The split of the masculine from the feminine element is the strongest issue here, causing rigidity, stiffness, and in the end (like in the Conium family) to dryness and suppression of the feminine, emotional level. Relationship will be an issue in the beginning of the column, later to be shifted to suppression of the heart and relationships, competition, work, duties, rules, religion and rigidity. Prominent remedies are Rose, Crat, Anac, Rhus-t and Con.

In the Sixth Column (The Group), one meets the world at large, stands up to it, fights with it, conquers one's place and defines one's place in it. The sixth column fits our time: an age of individuality that verges on egotism. Here the feminine and masculine had not recovered from the split, thus fighting amongst themselves, always on 
Table 2 Wondrous Order: The table at a glance.

\begin{tabular}{|c|c|c|c|c|c|c|}
\hline Old age & No Remedies & Arales & $\begin{array}{l}\text { Empty } \\
\text { column }\end{array}$ & $\begin{array}{l}\text { Zingiberales } \\
\text { Orchidales }\end{array}$ & Dioscoreales & \\
\hline Young adult & & & $\begin{array}{l}\text { No plants } \\
\text { here }\end{array}$ & $\begin{array}{l}\text { Orchidales } \\
\text { Juncales }\end{array}$ & Liliales & \\
\hline Adolescence & & & & Graminales & & \\
\hline School age & & Aracales & & & & \\
\hline \multicolumn{7}{|l|}{ Early childhood } \\
\hline \multicolumn{7}{|l|}{ Babyhood-basic trust } \\
\hline \multicolumn{7}{|l|}{ Beginning of life } \\
\hline \multicolumn{7}{|l|}{ Before birth } \\
\hline & ALISMATIDAE & ARECIDAE & & COMELIDS & LILIDAE & \\
\hline \multicolumn{7}{|l|}{ Monocotyledons } \\
\hline & $\begin{array}{l}\text { Before } \\
\text { separation }\end{array}$ & Here or there & The Hero & $\begin{array}{l}\text { Nourishing } \\
\text { Maturity }\end{array}$ & $\begin{array}{l}\text { The Other } \\
\text { Relationship }\end{array}$ & $\begin{array}{l}\text { The Group } \\
\text { in the world }\end{array}$ \\
\hline \multicolumn{7}{|l|}{ Dicotyledons } \\
\hline & Magnolids & Hamamelids & Caryophyllids & Dillenids & Rosids & Asterids \\
\hline $\begin{array}{l}\text { Birth, before life, connection to the neither world, } \\
\text { unwillingness to be born, difficulties in confronting } \\
\text { the self or the inner world Deep connections to the }\end{array}$ & $\begin{array}{l}\text { Magnoliales } \\
\text { Illiales }\end{array}$ & Urticales & & $\begin{array}{l}\text { Dileniales } \\
\text { Theales }\end{array}$ & $\begin{array}{l}\text { Rosales } \\
\text { Myrtales }\end{array}$ & Polemoniales \\
\hline
\end{tabular}

subconsciousness, myths. The shaman.

\begin{tabular}{|c|c|c|c|c|c|}
\hline $\begin{array}{l}\text { Beginning of life [oral stage] feeling secure about } \\
\text { existence, experiencing basic stability, first connec- } \\
\text { tion to mother. Acknowledging the other versus } \\
\text { autistic isolation, suspicion, disbelief, hopelessness. }\end{array}$ & Piperales & Urticales & Saraceniales & Fabales & \\
\hline $\begin{array}{l}\text { Infancy [Anal stage], autonomy, dependence, } \\
\text { [mother time] separation borders (skin diseases), }\end{array}$ & Laurales & $\begin{array}{l}\text { Hamameli- } \\
\text { dales }\end{array}$ & Malvales & $\begin{array}{l}\text { Geraniales } \\
\text { Malpigiales }\end{array}$ & Gentianales \\
\hline
\end{tabular}

getting control. The Will formation, shame,

criticism, being oneself versus self-doubt.

\begin{tabular}{|c|c|c|c|c|c|c|}
\hline $\begin{array}{l}\text { Early childhood, play, curiosity, inquisitiveness, } \\
\text { pulling apart. Initiative - or none. Paralysis, sex, } \\
\text { penetration. Unable to take role or set a goal. }\end{array}$ & $\begin{array}{l}\text { Aristolo- } \\
\text { chiales } \\
\text { Ranunculales }\end{array}$ & $\begin{array}{l}\text { Hamameli- } \\
\text { dales }\end{array}$ & $\begin{array}{l}\text { Caryophy- } \\
\text { liiales }\end{array}$ & Malvales & $\begin{array}{l}\text { Malpigiales } \\
\text { Violales } \\
\text { Euphorbiales }\end{array}$ & $\begin{array}{l}\text { Gentianales } \\
\text { Scrophular- } \\
\text { iales }\end{array}$ \\
\hline $\begin{array}{l}\text { School time, latency, capability sense, preparation } \\
\text { to life [father time], learning norms and rules, be- } \\
\text { ginning of social learning. Unreadiness to learn, }\end{array}$ & Ranunculales & Juglandales & $\begin{array}{l}\text { Caryophy- } \\
\text { liiales }\end{array}$ & & $\begin{array}{l}\text { Sapindales } \\
\text { Cornales } \\
\text { Rhamnales }\end{array}$ & $\begin{array}{l}\text { Scrophular- } \\
\text { iales }\end{array}$ \\
\hline
\end{tabular}

feeling inadequate, not fitting in, inferiority. Not recognizing roles. No purpose

\begin{tabular}{|c|c|c|c|c|c|c|}
\hline $\begin{array}{l}\text { Adolescence, identity integration or confusion. } \\
\text { Self-image reflected from outside. Body image. } \\
\text { Adolescence themes: freedom, excitement, search } \\
\text { meaning, imaginations, fancies and planning. De- } \\
\text { pendence on group. Looking for meaningful figures. }\end{array}$ & & Myricales & $\begin{array}{l}\text { Polygonales } \\
\text { Plumbagi- } \\
\text { nales }\end{array}$ & Primulales & Rhamnales & Rubiales \\
\hline $\begin{array}{l}\text { Early adulthood, young adult, establishment of } \\
\text { independence, of position. Breaking off depen- } \\
\text { dence, developing capability to real friendship and } \\
\text { caring to the other, > inability to intimacy, isolation. } \\
\text { Forming love relationships and partnership. }\end{array}$ & & & & & Santanales & Lamiales \\
\hline $\begin{array}{l}\text { Adulthood, creativity and fertility. Ability to care } \\
\text { and concern about the other, to give. Ability to de- } \\
\text { vote to ideas, to higher ideal. Finding self-expres- } \\
\text { sion. Versus selfishness, not changing, conserving. }\end{array}$ & Papaverales & Fagales & & $\begin{array}{l}\text { Ericales } \\
\text { Cucurbitales } \\
\text { Capprales }\end{array}$ & $\begin{array}{l}\text { Celastrales } \\
\text { Apiales }\end{array}$ & $\begin{array}{l}\text { Dispacales } \\
\text { Campanu- } \\
\text { lales } \\
\text { Asteridales }\end{array}$ \\
\hline $\begin{array}{l}\text { Old age, completion and wisdom. Retirement, } \\
\text { preparing for death, towards unification of the I. }\end{array}$ & Papaverales & & & $\begin{array}{l}\text { Capparales } \\
\text { Salicales }\end{array}$ & Apiales & Asteridales \\
\hline
\end{tabular}
Inability to collect, understand and unify life impressions, leads to bitterness, hostility, dissatisfaction, life has been a waste, despair. Dependency and fear of death. End of any process.

guard, causing the intra-relationship to be difficult and physical infertility at times. Also the need of the now fully developed
Ego to display itself, prove one's worth and find one's place in society can escalate to a clash with the world. Physically this can be expressed as allergies or a tendency to get worms: any other thing that violates one's boundaries or is even perceived to do it. 
On the one hand it has over sensitivity to the world's impressions, on the other hand it shows ambition and aggression: "the developed Ego fights back". The sixth column expresses a battle to function within a group, while yet maintaining one's hardearned individuality. Prominent remedies are Verat, Lil-t in the Monocots and Bell, Stram, Coff, Chin, Nux-v, Ign, Menth, Abrot, Cham and Arn - in the Dicots.

This is the end of our journey, and, perhaps, a preparation for the seventh stage, where all will be returned to the unified state, keeping a complete awareness of the uniqueness that will have been attained.

Development across the Columns

All columns are divided by levels of development - The rows (which follow E. Erikson's levels of development [2]). The rows express the lesson of each column, initiating the journey at a juvenile and unprepared state, evolving to maturity and eventually growing old and ending. Priming itself to begin the next step in the journey.

The columns are constructed according to Jungian developmental stages and Kabbal- istic lore. The human journey toward acquiring awareness finds its parallel in a number of developmental sequences: the developmental stages of the minerals, the progress of the history of humanity, the first six chakras and the six first days of creation. Like a gigantic fractal, the world demonstrates its patterned rules of creation in every aspect of life, all in a wondrous order.

\section{Wondrous Order book and schema}

The Table of Plants cannot entirely be explained in one article, the above is only the essence, a short portrayal, but the information perceived through the plant table schema can be easily validated by being compared to one's knowledge of remedies and cases.

An extensive description and much more information is available in my book "Wondrous Order". Sadly, for the time being, the book is only available in Hebrew. However, it is in the final stages of translation into English so it should be published in a few months' time. For those interested in making first inroads to using the Plants schema, please consult my website.

\section{References}

${ }^{1}$ Desai R. Re-exploring our Magnificent Plants. New Delhi, India: B. Jain; 1999

2 Erikson EH. Childhood and Society. New York/London: W. Norton \& Company Inc.; 1950, 1963

\section{Vita}

Michal Yakir is a former chairwoman of the Israeli association for homeopathy. She is editor of the IACH Bulletin, teaches homeopathy in Tel-Aviv, Israel, and lectures on the Plants Table.

Michal Yakir, PhD, RCHom

Nahal Yarkon 21

Modiin 71700

Israel

Internet:

http://www.homeopathy-plants.com

E-mail:m-yakir@bezeqint.net 